\title{
Zorunlu Göç Sürecinde Sosyal Ağlar; Şanlıurfa'daki Suriyeli Sığınmacılar
}

\section{Social Networking in Forced Migration: The Case of Şanlıurfa City}

\author{
Hakan Gülerce ${ }^{1} \oplus$, Ekrem Demir ${ }^{2}$ (C)
}

Öz

Türkiye 2011 yılından bu yana Suriye'de yaşanan iç karışıklıklar ve şiddet nedeniyle kitlesel bir göç sürecini tecrübe etmektedir. Milyonlarca insan zorunlu olarak yerlerinden edilerek Türkiye'ye giriş yapmıştır. Türkiye'de geçici koruma kapsamına alınan Suriyeli sığınmacılar ağırlıklı olarak sınır illerinde ve büyükşehirlerde yaşamaktadır. Şanlıurfa yarım milyona yakın sığınmacıyla bu iller arasında ilk sıralarda yer almaktadır. Sağııkı bir göç yönetişimi için sığınmacıların göç süreçlerinin analiz edilerek anlaşılması hayati önem taşımaktadır. Bu çalışmada Suriyeli sığınmacıların Şanlıurfa iline göç süreçleri sosyal ağlar kuramı ile açıklanmaya çalışılmıştır. Bu kapsamda sığınmacıların yaşadıkları zorunlu göç süreci, Şanlıurfa'da yaşamayı tercih sebepleri, yaşam biçimleri, gelecek niyetleri ve zorunlu göçten kaynaklı yaşanan sıkıntılar ele alınmıştır. Nitel araştırma yönteminin kullanıldığı bu çalışmada, 2021 yılı Nisan-Mayıs aylarında 11 Suriyeli aile temsilcisi ile yarı-yapılandırılmış derinlemesine mülakatlar yapılmıştır. Bu mülakatlardan elde edilen veriler analiz edilmiştir. Suriyeli sığınmacılar her ne kadar ülkelerini zorunlu olarak terk etmek durumunda olsalar da göç sürecinde aldıkları kararlarda akraba, arkadaş ve tanıdıklarından oluşan sosyal ağları kullandıkları ortaya çıkmıştır. Daha önceden göç eden sığınmacıların yeni geleceklerle yol gösterici ve onların göç süreçlerini kolaylaştırıcı oldukları görülmüştür. Bu durum göçün sürekliliğini ve göçmenlerin Türkiye'nin belirli bölgelerinde göçmenlerin neden olmuştur. Bununla birlikte göçmenlerin gelecek niyetleri içerisinde yakın vadede ülkelerine geri dönüş planları görünmemektedir.

\section{Anahtar Kelimeler}

Suriyeli sığınmacılar, Zorunlu göç, Sosyal ağlar kuramı, Şanlıurfa

\footnotetext{
1 Sorumlu Yazar: Hakan Gülerce (Dr. Öğr. Üyesi), Harran Üniversitesi, Fen-Edebiyat Fakültesi, Sosyoloji Bölümü, Şanlıurfa, Türkiye. E-posta: hakangulerce@harran.edu.tr ORCID: 0000-0003-3601-5725

2 Ekrem Demir (Yüksek Lisans Öğrencisi), Ankara Sosyal Bilimler Üniversitesi, Sosyal Bilimler Enstitüsü, Ankara, Türkiye. E-posta: ekremdemir34@gmail.com ORCID: 0000-0002-2291-3842
}

Atıf: Gulerce, H. ve Demir, E. (2021). Zorunlu Göç Sürecinde Sosyal Ağlar; Şanlıurfa'daki Suriyeli Sığınmacılar. Journal of Social Policy Conferences, 81, 185-211. https://doi.org/10.26650/jspc.2021.81.973727 


\begin{abstract}
Turkey has been undergoing a mass migration since 2011 due to internal turmoil and violence in Syria. Millions of people have been forced to enter Turkey, having been displaced. Syrian asylum seekers, who are under temporary protection in Turkey, mostly live in border provinces and metropolitan areas. Şanlıurfa ranks first among these provinces, with nearly half a million refugees. In the interest of effectively managing this influx, it is vital to analyze and understand the migration process for asylum seekers. This study aims to explain the migration process of Syrian asylum seekers to Şanlıurfa using the theory of social networking. In this context, the forced migration process experienced by asylum seekers, the reasons for choosing to live in Şanlıurfa, their lifestyles, future intentions and the problems experienced due to forced migration are discussed. The data for this study were collected using a qualitative research method, whereby semi-structured in-depth interviews were conducted with 11 Syrian families throughout April and May 2021. The data obtained from these interviews were then analyzed. Although Syrian asylum seekers have to leave their country forcibly, it has been revealed that they use social networks consisting of relatives, friends, and acquaintances to help them determine their plan of action during the migration process. It has been observed that asylum seekers who migrated prior guided and assisted the new comers during the migration processes. This situation has contributed to the facilitating of further immigration throughout certain regions of Turkey.
\end{abstract}

\title{
Keywords
}

Syrian asylum seekers, Forced migration, Migrant networks, Social cohesion, Şanlıurfa 


\section{Extended Summary}

The phenomenon of migration, which is the desire of a people to leave one place for another in search of a better life, leaves a permanent mark on the lives of individuals and societies. Migrations of peoples is a part of human history; it continues to occur and plays an important role in shaping and transforming civilizations. Particularly in recent years, the number of people who set out for various reasons, such as economic opportunities, education, and work, as well as fleeing from war. Thus, many social scientists, especially Castles and Miller, refer to the current period as "the age of migration" (Castles \& Miller, 2008). Turkey is not left out of this sociological process, as it is among the countries most affected by migration, especially the forced migration in recent years. The nature of migration has adopted different forms throughout history, and with the development of technology and evolving methods of transportation, the number of people migrating has continued to increase day by day. In addition, the number of people who had to leave their country and seek refuge in another country has increased due to wars and internal conflicts in various parts of the world. Turkey, which is the geographical junction between two continents, finding itself on the migrational path for many immigrants, has become home to millions of immigrants and asylum seekers in recent years. Millions of people have had to leave their homes due to internal turmoil and violence in Syria since 2011, forcing them to migrate to surrounding countries. Turkey is one of these countries. According to the data of the Presidency General of Migration Management of the Republic of Turkey, there are 3,688,093 Syrian asylum seekers under temporary protection status in Turkey as of July 07, 2021 ("Presidency of Migration Management" 2021). A significant number of asylum seekers living in Turkey live in the Syrian border provinces of Turkey for various reasons. For example, as of July 07, 2021, 424,039 Syrian asylum seekers live in Şanlıurfa; 452,985 in Gaziantep; 105,132 in Kilis; and 435,881 in Hatay. These figures reveal that more than half of all asylum seekers in Turkey are in this region. This can be explained both by the strong immigrant networks in these border regions and by the cultural similarities. This study analyzes migration, migration processes, and associated problems in the sample of immigrants living in Şanlıurfa. Firstly, the theoretical framework and literature regarding the phenomenon of migration were stated; then, the network theory, which is the focal point of the study, was examined, and detailed theoretical information about that theory was provided. The basis of the 
relationship network theory is the existence of social networks established by immigrants in the country where they migrate, as well as the existence of social networks established between the country the migrants leave and the country receiving the migrants and the influence of these networks on ongoing migration (Çağlayan, 2006, s. 85). Individuals who immigrate to a host country for the first time have some difficulties in the migration process; however, immigrants who migrate there afterward do not have to suffer the same difficulties owing to the information sharing of immigrants who preceded them. Because of this information sharing between those now-established at their final destination and those still en-route, subsequent migrations entailing fewer costs and less risk are further assured. This causes the number of immigrants to increase and migration to become permanent. Therefore, these social networks established among immigrants also determine the future of migration to a significant extent. In the study, it was understood that Syrian asylum seekers were influenced by their close relations, such as spouses, friends, and relatives who had migrated to Turkey prior to making the decision to immigrate, and that the people who migrated earlier helped those who migrated later. Thus, new migrants were guided by the experiences of those who came before when adapting to their host community. In the last section of this study, the migration process from Syria to Turkey is discussed within the framework of network theory specific to the Şanllurfa province. Data from in-depth interviews with 11 Syrian families were analyzed using a qualitative research model. Migration processes of Syrian asylum seekers in Turkey have been examined within the framework of network theory, which is a well-known migration theory. The study revealed that asylum seekers in Şanlıurfa experienced significant problems in terms of language barriers, access to life resources, education, employment, and access to public services. In addition, the social networks established by the immigrants among themselves had a strong influence in the migration processes of subsequent asylum seekers from Syria. The data analysis revealed that social networks have a crucial place in the forced migration processes of Syrian asylum seekers and the continuity of the migration in general. 


\section{Giriş}

Dünyada yaşanan çeşitli güvenlik sorunları, savaşlar ve şiddet olayları nedeniyle milyonlarca insan zorunlu göçe maruz kalmıştır. Birleşmiş Milletler Mülteciler Yüksek Komiserliği’nin verilerine göre dünya üzerinde 2019 yılı sonu itibarıyla 79,5 milyon insan zorla yerinden edilmiş bulunmakta ve bu kişilerin 29,6 milyonu mülteci konumunda kendi ülke toprakları dışında hayatlarını sürdürmektedirler ("Suriye Acil Durumu", 2021). Genel olarak zorunlu nedenlerden dolayı göç eden insanlar için sığınmacı veya mülteci kavramları kullanılmaktadır. ${ }^{1}$ Özellikle savaş ve şiddet ortamlarından uzaklaşmak isteyen sığınmacılar daha çok kendine en yakın ülkelere göç etmeye başlamışlardır. Göç veren ülke konumundan göç alan ülke konumuna geçen ülkelerden biri olan Türkiye ise bir zamanlar göçmenler tarafindan sadece transit ülke olarak kullanılmaktayken son yıllarda ülkedeki ekonomik, sosyal ve hukuki gelişmelerden dolayı artık milyonlarca göçmene ve sığınmacıya ev sahipliği yapan bir ülke konumuna gelmiştir. Türkiye'de yaşanan bu göç sürecinin devam ettiği göz önünde bulundurulduğunda sığınmacıların göç etme isteklilikleri, süreçleri ve yaşanan sorunların yerelde yapılacak çalışmalarla tartışılması gerekmektedir.

Göç, insanlık tarihi boyunca medeniyetlerin şekillenmesinde ve dönüşmesinde önemli rol oynayan sosyolojik bir olgudur. İnsanların daha iyi bir yaşama ulaşmak için bir yerden başka bir yere (ülke içerisinde veya farklı bir ülkeye yönelik) coğrafi olarak hareketliliğini ve geçici veya kalıcı olarak yerleşmesini ifade eden göç olgusu (Adigüzel, 2017, s. 3; Bartram, Poros, \& Monforte, 2017, s. 13) bireylerin ve toplumların yaşamında kalıcı izler bırakmaktadır. Ekonomik olarak daha iyi bir yaşam sürmek, terör ve şiddetten uzaklaşmak, eğitim görmek

1 Türkiye'de özellikle Suriye göçü yazınında ciddi bir kavram karmaşasından söz edilebilir. Türkiye'deki Suriyelileri ifade etmek amacıyla sığınmacı, mülteci, göçmen, vb. gibi kavramlar kullanılmaktadır. Bu kavramların kullanılmasında çeşitli açılardan bakıldığında farklılıklar bulunabilir. Bu çalışmada sığınmacı kavramı tercih edilmiştir. Aslında Türkiye'de yaşayan Suriyeliler Türkiye'nin 1951 Cenevre Anlaşmasında koymuş olduğu coğrafi çekinceden dolayı geçici koruma altına bulunmaktadırlar. Bu bağlamda düşünüldüğünde hukuki olarak mülteci kavramı kullanılamamaktadır. Sığınmacı kavramı mülteci olmak için başvuru yapmış ancak mültecilik başvurusu henüz karara bağlanmamış ve geçici bir süre koruma altında bulunan kişiler için kullanılmaktadır (Bulut \& Akın, 2020, s. 13). Diğer bir ifadeyle sığınmacılık, mülteci olarak uluslararası koruma arayan ancak bu statüyü resmi olarak henüz elde etmemiş olan kişileri ifade eden bir durumdur. Resmi statüleri değerlendirme aşamasında olan sığınmacıların mültecilere benzer ama çeşitli farklılıklar içeren hakları bulunmaktadır. Örneğin bu başvuru süreci içerisinde menşei ülkelerine zorla geri gönderilemezler ve temel haklarının korunması gerekir (Sakız, 2019, s. 2; Yıldız, 2017, s. 43). Bu bağlamda düşünüldüğünde Türkiye'de yaşayan geçici koruma altındaki Suriyelileri ifade etmek için sosyolojik olarak sığınmacı kavramının kullanılmasının daha doğru bir tercih olacağı düşünülmüştür. 
ve çalışmak gibi çok çeşitli sebeplerle göç eden insanların sayısı özellikle bu yüzyılda oldukça fazla artmıştır (Ökten, 2017, s. 156). Castles ve Miller içinde bulunduğumuz dönemi iletişim ve ulaşım teknolojilerinin gelişmesiyle birlikte artan nüfus hareketliliği nedeniyle "göçler çağı" olarak adlandırmaktadırlar (2008). Göç olgusu günümüze kadar şekil değiştirerek gelmiştir. Teknolojinin gelişmesi ve ulaşım imkânlarının artmasıyla birlikte göç eden insanların sayısı da günden güne artmaya devam etmektedir. Bu gelişmelerin yanı sıra dünyanın çeşitli bölgelerinde çıkan savaşlar ve iç çatışmalarla birlikte ülkesini terk etmek zorunda kalan ve sığınacak başka bir ülke arayan insanların sayısı da her geçen gün artmaktadır. Coğrafi konum olarak kıtaların buluşma noktası olan ve birçok göçmen için göç güzergâhı yolu üzerinde bulunan Türkiye, son yıllarda sayıları milyonlarla ifade edilen göçmene ve sığınmacıya ev sahipliği yapmaktadır. Bu bağlamda Türkiye hem göç alıp veren hem de göç güzergâhında bulunan bir ülke olarak değerlendirilmektedir.

Türkiye'de son on yıldır zorunlu göç olgusu toplumun önemli bir gündem maddesi olarak yerini korumaktadır. Özellikle Suriye'de çıkan iç karışıklıklar nedeniyle Türkiye'ye göç eden sı̆̆ınmacıların sayıca yoğunluğu bakımından değerlendirildiğinde göç ve sığınmacılık konuları gündemdeki yerini daha uzun yıllar koruyacağa benzemektedir. Özellikle Suriye'den kitlesel göçün ilk başladığı yıllarda geçici misafirler olarak değerlendirilen sığınmacıların zamanla kalıcı olduklarının anlaşılması (Erdoğan, 2020) üzerine toplumda daha fazla yankı bulur hale gelmiştir.

Türkiye'de yaşayan geçici koruma kapsamında kayıtlı bulunan Suriyeli sığınmacıların sayısının dört milyona yaklaştığı ve yüz binden fazla sığınmacının Türk vatandaşlığına geçtiği $i^{2}$ düşünüldüğünde artık sığınmacıların kalıc1lığı, devam eden göç süreci ve toplumsal uyum konuları üzerinde çalışmaların yapılması gerekliliği ortaya çıkmıştır. Bu çalışmada Şanlıurfa ilinde yaşayan sığınmacıların Şanlıurfa'yı tercih sebepleri, yaşam biçimleri ve gelecek planları sosyal ağlar kuramı yardımıyla anlaşılmaya çalışılacaktır. Özellikle göçmenlerin Şanlıurfa ilini tercih etmelerindeki temel nedenler, neden bu ilde kalmaya devam ettikleri, yaşanan sosyal uyum sorunları gibi konular göçmenlerle yapılacak görüşmelerle ortaya çıkacak saha çalışmasıyla desteklenecektir.

2 Bu konuda resmi kurumlardan net bir istatistik alınamamaktadır. Burada verilen bilgi İçişleri Bakanı Süleyman Soylu'nun 2019 yılında bir toplantıda sözlü olarak yaptığı açıklamaya dayanmaktadır. Bkz: https://tr.euronews.com/2019/08/02/bakan-soylu-92-bin-suriyeliye-vatandaslik-verildi-suleyman-soylu Dolayısıyla 2021 yılında bu rakamın önemli ölçüde arttığı tahmin edilebilir. 
Böylelikle bu çalışmanın göçmen ve yerel halkların birlikte yaşaması ve kaynaşması yönünde yapılacak politikalara yön vermesi beklenmektedir.

\section{Metodoloji}

Göçmenler tarafindan hedef ülkelerin belirlenmesinde birçok faktör bulunmaktadır. Özellikle göç süreçlerinin daha iyi anlaşılabilmesi için çeşitli kuramlar oluşturulmuş ve bu kuramlar ışığında göç olgusu incelenmiştir. Bu çalışmada ise göçü bir süreç olarak gören ve göçün nedeninden ziyade göçün devamında etkili olan sosyal ağları inceleyen sosyal ağlar kuramı üzerinden yapılacak bir saha araştırması ile değerlendirme yapılacaktır.

Çalışma, göç ve süreçlerini Şanlıurfa'da yaşayan Suriyeli sığınmacıların Şanlıurfa' da yaşamayı neden tercih ettiklerini, yaşam biçimlerini ve gelecek niyetlerini sosyal ağlar kuramından yararlanılarak ve saha çalışması desteğiyle tartışmaya açacaktır. Çalışmanın sorularına cevap bulmak amacıyla nitel araştırma yöntemi kullanılmıştır. Nitel araştırma, yapılandırılmış veya yapılandırılmamış gözlem, görüşme ve doküman inceleme gibi nitel veri toplama tekniklerinin kullanıldığı, olgu ve olayların kendi doğal ortamları içinde gerçekçi ve bütüncül bir şekilde ortaya konulmasına yönelik nitel bir sürecin izlendiği bir araştırmadır (Yıldırım \& Şimşek, 2017, s. 39). Nitel araştırma yorumlayıcı ve anlamacı bir yaklaşıma dayanır. Bu çalışmada ise yarı-yapılandırılmış derinlemesine görüşme yoluyla toplanan veriler yorumlanmıştır. Bu görüşmeler, araştırma problemine ilişkin yüzeysel sorunlardan çok, kişilerin düşünce, görüş ve deneyimleriyle ilgili bilgi toplamak istendiğinde kullanılan bir tekniktir. Derinlemesine görüşmelerde az sayıda insanla görüşülerek çok detaylı bilgi elde edilmeye çalışılmaktadır (Bal, 2014, s. 2014). Bu bağlamda çalışmada Şanlıurfa'nın çeşitli ilçelerinde yaşayan farklı yaş gruplarından 11 Suriyeli sığınmacı aile temsilcisi (8 erkek, 3 kadın) ile derinlemesine mülakatlar yapılmıştır (Tablo-1). Yarı-yapılandırılmış olarak gerçekleştirilen derinlemesine mülakatlarda katılımcılara demografik özelliklerin yanı sıra göç nedenleri, göç sürecinde yaşananlar, sıkıntılar, Şanlıurfa'daki mevcut durumları ve gelecek planları üzerine genel sorular sorulmuştur. Aile temsilcileri genellikle ailenin ekonomik anlamda geçimini sağlayan ve ailenin aldığ 1 kararlarda en fazla etkisi olan kişiler olarak belirginleşmektedir. İlk görüşme Harran Üniversitesi'nde öğrenim gören Suriyeli erkek sığınmacı bir öğrencinin aile temsilcisiyle yapılmıştır. Diğer 
mülakatlar ise kartopu örneklem tekniği uygulanarak gerçekleştirilmiştir. Bu tekniği uygularken aile temsilcileri birbirlerine referans olduğundan görüşülen ve araştırmacı arasında verilerin sağlıklı toplanabilmesi için gerekli güven ortamı oluşmuştur. Her bir görüşme yaklaşık 50 dakika sürmüştür. Görüşmelerden elde edilen verilerde güvenlik gerekçesiyle katılımcıların isimleri gizli tutulmuştur. Görüşmeler Covid-19 Pandemisi şartları göz önünde bulundurularak telefonla Arapça olarak gerçekleştirilmiştir. Katılımcılara mülakatlarda isimlerinin yayınlanmayacağı ve üçüncü kişilerle kayıtların paylaşamayacağ bildirilerek ses kayıtları alınmıştır. Bu kayıtlar deşifre edilerek Türkçe diline tercüme edilmiş ve ikinci bir tercüman tarafindan tercümelerin güvenirliliği onaylanmıştır. Elde edilen veriler tasnif edilmiş ve söylem analizi yöntemi kullanılarak sosyal ağlar kuramı çerçevesinde değerlendirilmiştir. Çalışma bireylerden veri toplanarak gerçekleştirildiğinden sorumlu araştırmacı Harran Üniversitesi Sosyal ve Beşeri Bilimler Etik Kurulu'na başvurmuş ve yapılandırılmış mülakat formu için etik kurul onayı alınmıştır. Bunun yanında araştırma gönüllü katılım formu kullanılarak katılımcılardan bilgilendirilmiş onam alınmıştır.

Tablo 1

Katılımcllar ve Demografik Bilgiler

\begin{tabular}{lllll}
\hline & MESLEK & YAŞ & CINSIYYET & KAÇ YILDIR TÜRKİYE'DE \\
\hline G1 & Petrol Mühendisi & 53 & Erkek & 8 \\
G2 & Alternatif Tıp & 34 & Kadın & 2 \\
G3 & Müfettiş (Eğitim) & 65 & Erkek & 7 \\
G4 & Öğretmen & 62 & Erkek & 8 \\
G5 & Tercüman & 25 & Erkek & 8 \\
G6 & Çiftçi & 53 & Erkek & 9 \\
G7 & Öğrenci & 30 & Erkek & 8 \\
G8 & Ziraat Mühendisi & 42 & Erkek & 6 \\
G9 & Ziraat Mühendisi & 43 & Erkek & 4 \\
G10 & Ev Hanımı & 35 & Kadın & 5 \\
G11 & Ev Hanımı & 22 & Kadın & 8 \\
\hline
\end{tabular}

\section{Sosyal Ağlar Kuramı}

Sosyal ağlar bireylerin gündelik hayat tecrübelerinde önemli yere sahiptir. İnsanların yaşam biçimlerinin şekillenmesinde, alacakları kararlarda, iş hayatına katılımlarında vb. gibi önemli deneyimlerde sosyal ağlar etkisini göstermiştir. Genel olarak insanlar arasında sosyal ağları güçlü olan insanların çeşitli imkânlara daha kolay ulaştığı zayıf olanların ise daha zor ulaştığı kanısı 
hâkimdir. Ancak bu durum zayıf bağların önemini azaltmamaktadır. Örneğin Mark Granovetter, 1973 tarihli dönüm noktası niteliğindeki bir çalışmada, iş fırsatları için en iyi adayların yakın arkadaşlarınızdan (güçlü bağlar) ziyade daha uzak tanıdıklarınızdan (zayıf bağlar) gelme olasılığının daha yüksek olduğunu ortaya koymuştur (Granovetter, 1973). Diğer taraftan sosyal ağlar; aile bağları, arkadaşlık, toplumsal örgütler ve aracı kurumlar gibi bazı işlevsel yapıları ifade etmektedir. Boyd ise bu sosyal ağlar içinde en güçlü yapının aile olduğunu ve ailenin diğer yapılara göre göç etmede daha etkili olduğunu vurgulamaktadır (1989, s. 643). Ancak sosyal ağların zayıf veya güçlü etkileri sadece iş edinme gibi bir mekanizmalarda değildir. Örneğin sosyal sermayenin ortaya çıkmasına neden olan çeşitli mekanizmalar ve buların olumlu ve olumsuz sonuçlarını da vurgulanması gerekmektedir (Portes and Sensenbrenner, 1993). Gurak ve Caces ise göçmen ağlarının ekonomik, psikolojik ve sosyo-kültürel gibi birçok açıdan olumlu veya olumsuz yönleri olduğunu belirtmiş ayrıca bu ağların hem kısa hem de uzun vadede göçmenler üzerinde etki göstereceğinden bahsetmiştir. Bu ağlar kısa vadede para yardımı, bilgi sağlamada kolaylık ve hayata tutunabilme gibi destekler sağlayabilirken uzun dönemde daha çok büyük ölçekli maddi destekler, göçmenlerin bulunduğu yardım ağlarına katılma ve kişiye sosyalleşme duygusu yaşatma gibi etkileri olmaktadır (Gurak ve Caces, 1992, s. 152-153). Dolayısıyla sosyal ağların göç sürecinin birçok boyutunda önemli bir yeri olduğu ifade edilebilir.

Sosyal ağlar kuramı, ilişkiler ağı kuramı, network kuramı veya göçmen ilişkileri ağı kuramı gibi farklı kavramlarla ifade edilen bu kuram aslında 1990’11 yıllarda sosyolojide kullanılan "ağ” kavramından esinlenerek göç olgusunu açıklamak için kullanılmaya başlanmıştır (Güllüpınar, 2013, s. 72). Bu kurama göre öncü göçmenler öncelikle göç veren ve göç alan toplumları birbirine bağlayan bir alt yapı oluştururlar ve bu bağlantı göç veren toplumdaki diğer bireylere göç etme imkânı tanır. Böylelikle yeni göç akınları, kurulmuş olan bu ağ1 harekete geçirir ve sonradan göç edenler ilk gelen göçmenlerin tecrübelerinden faydalanırlar. Bu şekilde göç kendini sürekli devam ettiren bir süreç olarak ortaya çıkar (Wilpert, 1992; Yalçın, 2004, s. 50). Dolayısıyla göçmenler arası ağ ne kadar kuvvetliyse göç süreci o kadar özendirici ve teşvik edici olmaktadır. Buradan yola çıkarak sosyal ağlar kuramının göçmenlerin göç nedenleri, göç süreçleri ve göç ettikleri yeni yerleşim yerlerindeki mevcut durumlarının anlaşılmasında açıklayıcı olmaktadır denilebilir. 
Her göçmen topluluğu gittiği ülkede hem kendi aralarında hem de ev sahibi toplum ile çeşitli ilişki ağları geliştirmektedir. Söz konusu bu durum göç sosyolojisi alanındaki çeşitli teoriler tarafından tartışılmaktadır. Ağ teorisi de bu kuramlardan biri olup genel olarak göç eden toplumların gittikleri yerlerde oluşturdukları ağlara yoğunlaşmaktadır (Kaya, 2017, s. 18). Sosyal ağlar kuramı, göçmenlerin menşe ülkeleri, vardıkları ülke, eski göçmen, yeni göçmen ve varış ülkesinde yaşayan halk arasında ortak köken, hemşerilik, soydaşlık ve dostluk gibi insanlar arasındaki bağlantılara (sosyal ağlar) gönderme yapan bir kuramdır. Sosyal ağlar kuramının dayandığı varsayımlar özet olarak şu şekilde siralanabilir (Abadan-Unat, 2017, ss. 64-65):

1. Sosyal ağlar, göçü özendirerek göçmenlerin göç etme isteğini artırmaktadır.

2. Sosyal ağlar göçün meydana getirdiği maliyetleri ve içerisinde yer alan riskleri azaltmaktadır.

3. Sosyal ağlar, kurumsallaştıkları ölçüde sosyo-ekonomik açıdan daha az seçici olmakta, gönderen ülke topluluğunu daha fazla temsil etmektedir.

4. Göçmenler arasında kurulan bu sosyal ağlar kurulduktan sonra göçmenleri kabul eden ülkeler bu göç akınını denetlemekte büyük zorluklar çekmektedir.

5. Göçmen ailelerin birleşmesini hedefleyen aile birleşimi gibi politikalar göçmenler arasındaki bu ağları daha da güçlendirmektedir.

Göçmenler yaşamış oldukları göç tecrübelerini çeşitli ilişki ağları vasıtasıyla yeni göçmenlere aktarma eğilimindedirler. Faist'e göre uluslararası göçlerde göçmenler kendilerinden önce giden göçmenlerin ayak izlerini takip ederek onlara bağımlı olmaktadırlar (Faist, 2003, s.236). Dolayısıyla her iki grup da göç sürecinde dayanışma içerisinde olmaktadır. Bu dayanışma ve dernekleşme sürecinde sosyal ağlar önemli rol oynamaktadır.

Faist'e göre sosyal ağların kurumsallaşması ve yerleşikleşmesinin sonucu dernekler ortaya çıkmaktadır (Faist, 2003). Göç edilen yerde göç sonrası sorunların çözümü ve uyum politikalarında sivil toplum kuruluşları önemli rol üstlenmektedir (Emini, 2018). Adıgüzel, göçmenlerin ilişki ağlarının sonucunda ortaya çıkan göçmen derneklerine değinmiştir. İlk başlarda göçmenler için vakit geçirme ve buluşma yeri olarak kurulan göçmen dernekleri daha sonraları 
göçmenlerin ev sahibi toplum ile kaynaşmasına ve yeni gelen göçmenlere yardımcı olan bir mekâna dönüşür. Türkiye'de kurulan hemşeri bu duruma örnek verilebilir (2017, s. 194). Türkiye'nin çeşitli illerinde farklı ülkelerden gelen göçmenler tarafindan kurulmuş yüzlerce dernek vardır. Bu derneklerin bazıları uyum çalışmaları ve göçmenlerin gündelik yaşamının kolaylaştırılmasına ilişkin faaliyet gösterirken bazıları da menşe ülkeden gelmek isteyen göçmenlere danışmanlık konusunda yardımcı olmaktadır.

Massey, sosyal ağlar kuramını göçmenlerin aileleri, arkadaşları ve ülkede kalan yakınlarını da içine alan karşılıklı ilişkiler ve oluşturulan ağların bir bütünü olarak tanımlamaktadır. Bu kişiler arasındaki ilişkilerin insanların göç etme olasılığını arttırmaktadır. Bunun nedeni bu ilişkiler ne kadar güçlü olursa göç etme maliyetinin ve risklerinin de o oranda düşeceği öngörülmüştür. Massey, bu düşüncelerden yola çıarak sosyal ağlar kuramını "azalan maliyetler" ve "azalan riskler" kavramlarıyla açıklamıştır (Massey vd., 2014). Yaşadığ1 ülkeden farklı bir ülkeye ilk kez göç eden bireylerin (ilk göçmenlerin) kendisinden önce yararlanabileceği herhangi bir deneyime sahip göçmenlerin olmadığı için göç etme maliyeti oldukça fazladır. Söz konusu göç yasal olmayan yollarla olacaksa bu maliyet çok daha fazla olacaktır (Massey vd., 2014, s. 28). Özellikle gelişmiş ülkeler artık gelişmemiş ülkelerden gelen yabancılara kapılarını kapatmaktadır bu da göç maliyetlerini önemli derecede yükseltmekte ve göç etmek isteyen kişileri yasal olmayan yollarla göç etmeye zorlamaktadır. İlk göçmenler ülkeye girdikten sonra arkada kalanlar için iş biraz daha kolay olmaktadır. Çünkü artık ilk giden göçmen tecrübe kazanmış ve bu tecrübesi sayesinde geride kalan arkadaşlarına, akrabalarına veya yakınlarına yol göstermektedir. Bu sayede de göç etmenin maliyeti azalmaktadır (Massey vd., 2014, s. 29). Özellikle ilk giden göçmenler gittikleri ülkeye giriş için gerekli kuralları öğrendiklerinde arkada kalanlar için bu süreç daha az masraflı olacaktır. Eğer daha sonra gidecek göçmenler için yasal yollar bulunmuşsa maliyetle birlikte risklerde azalacaktır. Ancak yasal olarak gitmenin yolu bulunamadiysa kaçak göç etmenin maliyeti kendinden öncekine göre daha az olacaktır.

Göçmenler arasında kurulan sosyal ağların göçmene katkılarından en önemlilerinden biri de göçmenlerin göç ettikleri ülkeye gittikleri zaman yeni bir ülkeye alışma süreci ve bu süreçte temel ihtiyaçların nasıl giderileceği ile ilgilidir (Massey vd., 2014). Göçmenler gittikleri ülkede ev bulma, iş bulma, çevreye uyum sağlama gibi birçok yeni problemle karşılaşmaktadır. Bu süreçte 
göçmene en çok yardımcı olan kaynaklardan biri sosyal ağlardır. Göçmenler sosyal ağlar sayesinde bu tür zorlukları daha az maliyetle atlatabilirler. Örnek vermek gerekirse yeni bir şehre göç eden göçmen için iş bulmak oldukça zordur. Ancak kendinden önce oraya göç eden bir tanıdığının olması o göçmenin iş bulmasını daha kolaylaştıracaktır. Bu iddia sığınmacıların yoğunluklu olarak yaşadığı üç şehir olan Gaziantep, Şanlıurfa ve Hatay'ı kapsayan bir çalışma ile doğrulanmaktadır. Çalışmaya göre bu illerde yapılan anket sonuçlarına göre, sığınmacıların çalışabilecek yaşta olanlarının yaklaşık \% 72'sinin bir iş bularak çalıştığı görülmektedir. Yine aynı çalışmada sığınmacılar kazançlarının yetersiz olduğunu ve geçim sıkıntısı yaşadıklarını ifade etmişlerdir. (Sönmez \& Ayik, 2020, s. 72). Bu durum göçmen ağlarının iş bulmayı kolaylaştırdığını ancak çalışma şeklinin önemli bir kısmının kayıt dışı olduğunu göz önünde bulundurduğumuzda çalışma koşullarının sıkıntılı olduğunu göstermektedir.

Göçmenler arasında kurulan ağlar sadece göçün maliyetini azaltmak ile kalmaz aynı zamanda göç süresince karşılaşılabilecek riskleri de minimuma indirir. Göç ağları geliştikçe göç sürecinde ve göç edilen ülkede karş1laş1labilecek risklere ilişkin geride kalanlara bilgi verilir ve bu geride kalanların göç süreci daha güvenli hale gelir. Böylelikle de azalan maliyetle birlikte risklerinde azalmasıyla teorik olarak kendi kendini devam ettiren bir süreç başlar (Massey vd., 2014: 29). Örneğin daha önce kaçak yollardan göç eden bir kişinin daha güvenli göç yolunu öğrenmesi sonucunda kendinden sonraki göç edecek kişilere bu bilgiyi vermesi o kişilerin aynı riskleri almasının önüne geçecektir. Buradan yola çıkarak hem göç sürecindeki maliyetlerin azalması hem de risklerin oluşturduğu endişelerin ortadan kalkması göç etmek istekliliğini artırmaktadır sonucuna varılabilir.

\section{Şanlıurfa'daki Suriyeli Sığınmacılar}

Coğrafi konum olarak kıtaların buluşma noktası olan ve birçok göç güzergâhı yolunda bulunan Türkiye, son yıllarda sayıları milyonlarla ifade edilen göçmene ve sığınmacıya ev sahipliği yapmaktadır. Özellikle Ortadoğu ülkelerinde meydana gelen savaşlar, iç çatışmalar ve siyasi olaylar yüz binlerce insanın Türkiye'ye sı̆̆ınmasına neden olmuştur. Birleşmiş Milletler'in verilerine göre Suriye iç savaşından etkilenerek başka ülkelere sığınan Suriyeli sayısı 6 milyondan fazladır ("Suriye Acil Durumu”, 2021). Yaklaşık aynı rakamda insanın da Suriye sınırları içerisinde zorunlu olarak yer değiştirdiği tahmin edilmektedir. 
Suriye'den diğer ülkelere yönelik yaşanan kitlesel göçten en çok etkilenen ülke hiç kuşkusuz Suriye'ye 911 kilometre kara sınırı bulunan Türkiye'dir. 2011 yılının Nisan ayında 252 Suriyeli sığınmacının Türkiye'nin Cilvegöz sınır kapısına gelerek başlayan Suriyeli sığınmacı akını bugün tahminlerin çok ötesine geçmiştir. Göç İdaresi Başkanlı̆̆ı'nın (GIB) yayınladığı verilere göre 2021 y1lı itibariyle Türkiye'de 4 milyona yakın kayıtlı geçici koruma ${ }^{3}$ statüsünde Suriyeli sığınmacı bulunmaktadır.

Suriye'de 2011 yılından bu yana devam eden iç karışıklıklar ve şiddet olayları yüzünden milyonlarca insan yurtlarını terk etmek zorunda kalmıştır. Zorunlu olarak yerlerinden edilen insanlar yoğunluklu olarak çevre ülkelere göç etmişlerdir. Türkiye bu ülkelerin başında gelmektedir. Türkiye'ye göç eden Suriyeli sığınmacı sayısı 2011 yılı sonunda 14.237 iken bu sayı 2013'te 224.655 'e ulaşmıştır. 2014 yılından itibaren hem Türkiye'ye gelen Suriyeli sığınmacı sayısında büyük bir artış olmuş hem de sığınmacılar artık Türkiye'nin çeşitli illerine doğru yönelmeye başlamışlardır. Göç İdaresi Başkanlığı verilerine göre Türkiye'de 07.07.2021 tarihi itibarıyla 3,688,093 geçici koruma kapsamı statüsünde Suriyeli sığınmacı bulunmaktadır. Türkiye zorunlu göç eden Suriyeli sığınmacılar için ilk yıllarda geçici barınma merkezleri kurularak onların acil ihtiyaçlarını karşılanmaya çalışılmıştır. Ancak zorunlu göçe maruz kalan sığınmacıların sayısının her geçen gün artmasıyla ülke içinde de ikamet etmelerine de izin verilmiştir. Göç İdaresi Başkanlığı'nın verilerine göre Türkiye'de yaşayan geçici koruma altındaki Suriyelilerin büyük kısmı illerde serbest şekilde yaşamlarını sürdürmektedirler. Sadece 60 bin civarında Suriyeli sığınmacı Geçici Barınma Merkezi adı verilen kamplarda yaşamlarını sürdürmektedirler (GİB, 2021). Türkiye'de geçici barınma merkezlerinin kapatılmasıyla birlikte sığınmacılar ülkenin çeşitli bölgelerine doğru göç etmişlerdir.

Suriyeli sığınmacıların zorunlu göç sürecinde Türkiye'yi tercih etmesinde coğrafi yakınlığın yanı sıra kültürel bağların da önemli etkisi bulunmaktadır (Karademir \& Doğan, 2019, s. 121). Türkiye’ye göç eden Suriyeli sı̆̆ınmacıların ilk hedefi büyük ölçüde Suriye sınırındaki iller olmuştur. Sığınmacıların büyük çoğunluğu Türkiye'ye giriş yaptıktan sonra kayıt altına alınarak şehir merkezleri

3 Türkiye’ye sığınma başvurusu yapan Suriyeli sığınmacılar için Türk hukuku "geçici koruma" statüsünü belirlemiştir. "Geçici koruma, kitlesel akın olaylarında acil çözümler bulmak üzere geliştirilen bir koruma biçimidir. Devletlerin geri göndermeme yükümlülükleri çerçevesinde kitleler halinde ülke sınırlarına ulaşan kişilere, bireysel statü belirleme işlemleri ile vakit kaybetmeden, uygulanan pratik ve tamamlayıcı bir çözüm yoludur” (Göç İdaresi Başkanlığı, 2021). 
veya kırsal alanlara yerleşmiştir. Çok düşük oranda sığınmacı sınır illerinde bulunan geçici barınma merkezlerine kalmıştır. Zamanla geçici barınma merkezlerinin kapanmasıyla birlikte sığınmacılara gitmek istedikleri iller için tercih hakkı verilmiştir. Buna rağmen sığınmacılar çoğunlukla aynı şehirlerde kalmayı tercih etmişlerdir. Ancak, zamanla sığınmacılar başta İstanbul, Adana, Konya olmak üzere Türkiye'nin birçok bölgesine dağılmıştır.

Göç İdaresi Başkanlığı'nın verilerine göre İstanbul, Gaziantep ve Hatay'dan sonra Suriyeli sığınmacıların yaşadığı en kalabalık il Şanlıurfa'dır. Şanlıurfa kayıt altına alınmış geçici koruma kapsamındaki Suriyeli sayısı Temmuz 2021 itibarıyla 424 bin kişidir (GİB, 2021). Şanlıurfa'da şehirde yaşayan Suriyeli sığınmacıların bu ilde kalmayı tercih etmelerinde hiç kuşkusuz ekonomik sebepler, akrabalıklar, kültürel ve coğrafi benzerlikler çok farklı sebepler bulunmaktadır. Özellikle coğrafi yakınlık ve kültürel benzerlik, akrabalık ilişkileri, göçmen ağları ve her an geri dönebilme umudu gibi sebeplerden dolayı Suriyelilerin büyük bir bölümü sınır illerinde yaşamaya devam etmektedir (Kaya, 2017). Göç İdaresi Başkanlığı verilerine göre Ocak 2021 itibariyle Hatay, Kilis, Gaziantep, Şanlıurfa, Mardin ve Şırnak illerinde toplam 1.514.393 sığınmacı yaşamaktadır (“GİB”, 2021). Örneğin bu illerden Kilis’te sığınmacı sayısı o ilde yaşayan yerel halktan daha fazladır.

\section{Bulgular}

\section{Göç Nedenleri}

Zorunlu göç ile ülkesini terk etmek zorunda kalan sığınmacıların göç etmelerindeki en büyük nedenin güvenlik sorunu olduğu bilinmektedir. Özellikle çeşitli anlaşmazlıklardan kaynaklanan şiddet, ekonomik zorluklar, hayatta kalma mücadelesi, mutluluk arayışı, kişiler üzerindeki çeşitli baskılar veya tehditler vb. gibi farklı koşulların oluşturduğu nedenlerle ortaya çıkan yer değiştirme zorunlu göç olarak tanımlanmaktadır (Bartram, Poros, \& Monforte, 2017, s. 151). Dolayısıyla zorunlu göç kişinin isteği dışında dışsal sebeplerle gerçekleşmektedir. Bununla birlikte bazı nedenler özellikle zorunlu göçe karar verme süreçlerini etkileyebilmektedir.

Yapılan görüşmelerde göçmenlerin göç kararı alma sürecinde akraba ve arkadaşlarının kendilerine yardımcı oldukları ortaya çıkmıştır. Bu destek ve yardımlarla göç eden kişilerin bir sonraki göçmenlere ve daha sonra göç 
edeceklere de yardımcı oldukları görülmüştür. Dolayısıyla bu göçmen dayanışması zorunlu göç sürecinde göçmenlerin karar almalarını kolaylaştırmaktadır. Örneğin bazı katılımcılar neden Türkiye’ye göç ettikleri ile ilgili sorulan bir soruya şu cevabı vermişlerdir:

Uzun zamandır tanıdığım bir arkadaşımla üniversiteden biz sürekli konuşuyorduk. Türkiye'ye ilk geldiğimde onun evine gitmiştim fakat ben geldiğimde o bir süre sonra İstanbul'a gidecekti. Ben de ona tamam dedim. Gideceği zaman ben kendime başka bir yer baktım ve yeni bir eve çıktım (G2, Kadın, 34).

Türkiye'ye gelmeden önce ilk göç ettiğimizde onlarla birlikte kalmak için bazı arkadaşlarımızla konuştuk. Anlaştıktan sonra Türkiye’ye göç etmek için yola çıktık (G9, Erkek, 43).

Dedem Türkiye'de yaşıyordu. Onun için Türkiye'ye göç etmeyi tercih ettik (G4, Erkek, 62).

Bulgular, özellikle düzensiz (yasadışı) 4 göç eden sığınmacılar göç yolculuğuna başlamadan önce gidecekleri yerdeki tanıdıklarıyla irtibata geçtiklerini göstermektedir. Böylelikle göç yolculuğuna daha bir güven ve istekle çıkmış olmaktadırlar. Aynı zamanda bu kişiler yeni yerleşim yerine geçtikten sonra tecrübelerini kullanarak yeni geleceklere de yol göstermeye başlamışlardır. Bu da sosyal ağlar kuramının öne sürdüğü önceki göçmenlerin daha sonra gelecek olan göçmenlere yardımcı olduğunu doğrulamaktadır. Bu durum göçmenlerin hem Türkiye'ye göçü tercih ederken hem de kalacakları şehri seçmelerinde sosyal ağları kullandıklarını göstermektedir. Örneğin görüşme yapılan katılımcılardan üçü “Türkiye'ye yerleştikten sonra Suriye'de bir tanıdığınız ya da bir akrabanız sizden Türkiye'ye göç etmek için yardım istedi mi?" sorusuna şöyle yanıt vermişlerdir:

4 Çalışmada Suriye'den Türkiye'ye pasaportsuz veya belgesiz bir şekilde gümrük kapıları haricinden giriş yapan sığınmacılar için yasadışı veya düzensiz göçmen kavramları kullanılmaktadır. Bu kavramlar özellikle Suriyeliler açısından kriminalize edici bir anlam taşımamaktadır. İlgili yönetmeliğin "Türkiye'de geçici koruma talebinde bulunan bireyler, Türkiye'ye girdiklerinde Türk makamları tarafından tespit edilirlerse veya makul bir süre içinde kendileri Türk makamlarına başvurur ve Türkiye'ye düzensiz (yasadışı) girişleri ve ülkede düzensiz (yasadışı) kalışları konusunda geçerli bir sebep sunarlarsa, Türkiye'ye düzensiz (yasadışı) yollarla girdikleri veya Türkiye'de düzensiz olarak kaldıkları için cezalandırılmazlar (idari para cezası gibi)" ibaresine göre ülkeye düzensiz giriş yapan Suriyeli sığınmacılar suç işlememiş sayılmaktadır ve bu nedenle herhangi bir cezaya çarptırılamayacakları açıkça ifade edilmiştir (UNHCR, 2021; GİB, 2021). Ancak bu çalışmada etik olarak kriminalize edici bir bağlam çağrıştırmaması için yasadışı geçiş yapan göçmenler için (giriş şekli bakımından) düzensiz göçmen kavramı kullanılmıştır. 
Evet, şu anda benden yardım isteyen akrabalarım var. Örneğin ben Şanlıurfa'ya yalnız başıma göç ettim ve ailem beni daha sonra takip etti (G3, Erkek, 65).

Sadece akrabalarım değil, bunun yanında, akraba olmayan kişilerin de bizden yardım talepleri var. Bunların çoğu, genellikle yasal statü, sağlık konuları veya birinci derece akrabalar arasında transfer ve yeniden birleşme izni olan çeşitli konularda yardım istemektedirler. Benden sonra dokuz kişilik ailem ve uzak yakın akraba komşularda gelenler oldu (G4, Erkek, 62).

Evet, Türkiye'ye gelmeden önce burada ki akrabalarımızdan yardım istedik. Aynı zamanda bu akrabalarımız sayesinde Şanlıurfa'ya gelmeye karar verdik. Ayrıca Suriye'de akrabalarımız var şuan gelmek isteyen yok ancak gelmek isteyen olursa akrabam olmasa dahi elbette yardım edeceğiz (G5, Erkek, 25).

Suriye'den Şanlıurfa'ya göç eden sığınmacıların daha sonra yeni göç edeceklere de herhangi bir endişe duymadan yardım ettikleri gözlemlenmektedir. Suriye'de kalan akraba ve tanıdıkların talepleri devam etmektedir. Bazı göçmen aileler yakın akrabalarla birlikte bazıları ise parçalı olarak göç ettikleri ortaya çıkmıştır. Aynı zamanda oluşturulan göçmen ağlarının insanların hangi şehre göç edeceklerine verdikleri kararda önemli rol oynadığı görülmektedir. Göçmenler arasında bu göç sürecinde ciddi bir dayanışmanın da hâkim olduğu gözlenmektedir. Yeni göç edecek insanlara yakınlık dereceleri olmasa bile destek olmak istedikleri anlaşılmaktadır.

Mülakatlara katılan on bir aileden sekizi düzensiz göçmen olarak Türkiye’ye geldiklerini ifade etmişlerdir. Özellikle düzensiz göçmenler göç yolculuğuna başlamadan önce gidecekleri yerdeki tanıdıklarıyla irtibata geçmişlerdir. Böylelikle göç yolculuğunu daha güvenli ve daha az maliyetli hale getirerek daha istekli bir şekilde yola çıkmışlardır. Sığınmacılar Suriye içinde güvenlik tehdidi nedeniyle sınıra ulaşmak zor olacağından ülke içinde genellikle kaçakçılar aracılığıyla göç etmektedirler. Dolayısıyla göç etme kararı vermede etkili olan sosyal ağlar göç süresince de kaçakçılar gibi bu işi tamamen ekonomik amaçlarla yapan kişiler ortaya çıkmaktadır. Sığınmacılar ise göç süresince meydana gelebilecek riskleri en aza indirebilmek için bu ağlara başvurmak durumunda kalmaktadırlar. 


\subsection{Göç Yolculuğu}

Ülkesinden zorunlu olarak göç etmek zorunda kalan sığınmacılar için en zorlu kararlardan biri de kuşkusuz hangi yollarla göç edeceğidir. Her ne kadar Suriye göçünün başından bu zamana kadar Türkiye açık kap1 politikası uygulamış olsa bile birçok sığınmacı için Türkiye'ye yasal yollarla girecekleri sınır kapısına ulaşmaları oldukça güçtür. Suriye'den Türkiye'ye göç eden Suriyeli sığınmacıların bir kısmının yasal yollardan Türkiye'ye ulaştıkları bilinse de önemli sayıda sığınmacı da yasadışı yolları kullanmak (düzensiz göçmen olmak) zorunda kalmıştır. Bu çalışmada mülakat yapılan 11 sığınmacı aile temsilcisinden sadece üçü yasal yolları kullanarak Türkiye'ye göç ettiğini belirtmiştir. Diğerleri yasa dışı yolları (düzensiz) kullanarak Türkiye’ye giriş yapmışlardır.

Sığınmacılar için göç etme kararını verdikten sonraki diğer bir karar bu göçün ne şekilde gerçekleşeceği üzerinedir. Burada sosyal ağlar kuramında öne sürdüğü gibi göçün hem ekonomik olarak maliyetini azaltan hem de göç esnasındaki riski azaltan sosyal ağların varlığı oldukça önemlidir. Göç sürecine yasadışı yollarla devam edilecekse devreye göçmen kaçakçıları girmektedir. Göç etmek isteyen kişinin göçmen kaçakçısına ulaşmasındaki amacı göç süresince meydana gelebilecek riskleri minimuma indirmek istemesidir. Aslına bakıldığında düzensiz göç en çok göçmenler için risk doğurmaktadır. Hatta bu nedenle göçmenler göç yollarında ölmektedir (Karasu, 2020, s. 105). Dolayısıyla buradan yola çıkarak göç sürecinin kolaylaştırılması yönünde çeşitli çalışmaların yapılması gerekliliği ortaya çıkmaktadır.

Göç esnasında ülke içinde yaşanan hareketlilikte de sığınmacılara yardımcı olan sosyal ağların bulunduğu bilinmektedir. Bu ağlar genellikle ülkenin farklı bir bölgesinde yaşayan akraba, tanıdık veya göçmen kaçakçıları olabilmektedir. Örneğin bazı katılımcılar göç etme kararı verdikten sonra hangi yollarla ülkeye giriş yaptıklarına ilişkin aşağıdaki ifadelere yer vermişlerdir;

...Babam yıllar önce Türkiye'ye geldi. Çünkü Türkiye'de bazı akrabalarımız var. Sabahın erken saatlerinde hazırlanmıştık. Akrabalarımızla vedalaştık ve Türkiye sınır kapısına doğru yola çıktık. Sınır kapısına ulaşmak için bir köye gitmemiz gerekiyordu. Köye gittik ve sınır kapısı kapalıydı o an ne kadar çok sevindik tekrar evimize döneceğiz diye fakat sevincimiz bir dakika sürdü. Babam 
“artık dönmeyeceğiz bu köyde benim tanıdığım bir aile var onlardan yardım isteyeceğiz" dedi. Kapı açılana kadar onlarda bekledik. Babamın tanıdığ 1 aileye gittik ve tam 11 saat bekledik sabah erken kapı açıldı ve giriş yaptık. Babamın arkadaşları bizi Akçakale kapısında bekliyordu sonra kendi evine gittik (G5, Erkek, 25).

Ben kararı aldığım andan itibaren bir kaçakçı ile görüştüm. Yanımda biraz altınım vardı. Miktarı söylediğimde o da tamam dedi. Ben sizi aradığımda gelirsiniz dedi. Ben de çocuklarımı ve kendimi hazırladım. Beni aradı ve onun olduğu yere gittim. Gittiğim yerde sadece kadınlar ve çocukları vardı. Bizi büyük bir kamyonun içine sakladı. Kamyonun kasasında epeyce uzun süre kaldık. Birkaç köyden geçirdi bizi. Bir süre sonra indik. Tel örgülerden sınırı geçeceğimizi söyledi. Sınıra kadar uzun süre yürüdük. Vardığımızda benden altınları aldı ve yanımda olan kadınlar da altınları ve mevcut paraları verdi. Paraları ve altınları alır almaz bizi bırakıp gitti. Biz de tel örgülerden geçmeye başladık. Benim elim yaralandı ve grubumuzda bulunan bir çocuğun daha ayağ yaralandı. Biz sınırdan geçtikten sonra nasıl ve nereye gideceğiz bilmiyorduk. Yürümeye başladık, çok yorulduk, sonra önümüze bir ana yol çıtı. Fakat nereye gideceğimiz bilmiyorduk. Karşımıza bir adam çıktı. Bizi Şanlıurfa'ya kadar getirdi (G2, Kadın, 34).

Göçmen kaçakçısına ihtiyaç duymadım köken olarak zaten Türk'üm. Ayrıca benim geniş çevrem olduğu için tanınmış biriydim. Bu da göç ederken bana kolaylık sağladı (G4, Erkek, 62).

Görüldüğü üzere Türkiye’ye göç eden sığınmacılar sınır kapılarının kapalı olduğu durumlarda daha güvenli bir yere düzensiz olarak göç etme ihtiyacı hissetmişlerdir. Çünkü sığınmacılar Suriye içinde güvenlik tehdidi nedeniyle sınıra ulaşmak zor olacağından ülke içinde genellikle göçmen kaçakçıları aracılığıyla göç etmektedirler. Dolayısıyla zorunlu göçte kolaylaştırıcı olan sosyal ağların yanında göçmen kaçakçılığ 1 da önemli rol oynamaktadır. Bu durum göç literatüründe göç endüstrisi kavramıyla ele alınmaktadır. Bu kavram göç sürecinde kolaylaştırıcı olarak rol alan seyahat acenteleri, işçi simsarları, tercümanları ve hatta otel sahipleri gibi göç hareketlerini yöneterek buradan gelir sağlayan kişi ve kurumları kapsamaktadır (Castles ve Miller, 2008, s. 162). Dolayısıyla göçmenler üzerinden gelir elde etmeye çalışan her kişi veya grup göç endüstrisine dâhil olmaktadır. Sonuç olarak sığınmacılar, göç süresince 
meydana gelebilecek riskleri en aza indirebilmek için hem sosyal ağlar vasıtasıyla edindiği bilgilere hem de göçmen kaçakçılarına ihtiyaç duymaktadır. Özellikle sınır geçildikten sonra sosyal ağlar daha yoğun bir şekilde devreye girmektedir. Sosyal ağlar vasıtasıyla sı̆̆ınmacılara ilk karşılaşma ve acil ihtiyaçlar konusunda destek sağlanmaktadır. Böylelikle göçmen, zorunlu göç dahi olsa, sosyal ağlar vasıtasıyla yeni yaşam yerine zamanla uyum sağlamaya çalışmaktadır.

\section{Göç Edilecek Şehrin Seçimi}

Sığınmacılar için varış ülkesine ulaşmadan önce verilmesi gereken kararlardan biri de varış ülkesine ulaştıktan sonra yaşanılacak yerin seçimi gelmektedir. Bu seçimde sosyal ağların etkisi önemlidir. Sosyal ağların özellikle göç edilecek şehrin seçimindeki rolünü kavrayabilmek için mülakatlara katılan sığınmacıların göç etme kararları üzerine sorular soruldu. Özellikle karar verme aşamasında Türkiye' de yaşayacağ 1 yeri seçmede hangi faktörlerin etkili olduğuna ilişkin verilen cevaplar sığınmacıların yaşayacakları yeri seçmelerinde sosyal ağların çok önemli bir etken olduğunu ortaya koymuştur. Örneğin bazı katılımcıların göç ederken neden Şanlıurfa ilini seçtiklerine ilişkin sorulan soruya şu ifadelere yer verilmiştir.

Urfa'da arkadaşlarım ve akrabalarımın varlı̆ğ (G1, Erkek, 53).

Akrabaların, arkadaşların ve tanıdıkların varlığı (G7, Erkek, 30).

Çünkü yerel derneklere ilişkilerim var (G3, Erkek, 65).

Biz Şanlıurfa'da yaşamayı akrabalarımızdan dolayı tercih ettik gideceğimiz yeri bir tanıdık olursa daha iyi diye düşündük ve ondan dolayı Şanlıurfa'da yaşamaya karar verdik (G5, Erkek, 25).

Şanlıurfa'da yaşamayı biz tercih etmedik. Amcam bu ilde yaşadığı için ve başka illerde tanıdığımız hiç kimse olmadı için burada yaşamaya devam ettik (G11, Kadın, 22).

Göç etmek için Türkiye en iyi en kolay ve en yakın ülkeydi. Ayrıca babam ve annem Urfa'daki sığınmacı kampında yaşıyordu. Bunun yanında Şanlıurfa'da akrabalarımız vardı. (G8, Erkek, 48). 
Bulgulara göre sı̆̆ınmacıların gidecekleri ülkede yaşayacakları yeri seçmesinde kurulan sosyal ağlar çok önemli bir yere sahip olduğu ortaya çıkmıştır. Mülakat yapılan çoğu sığınmacı Türkiye'ye gelmeden önce Şanlıurfa'da yaşamaya karar verdikleri görülmektedir. Sı̆ğınmacıların Şanlıurfa'yı tercih etmelerindeki temel sebeplerden birisi ise Şanlıurfa'da bulunan akrabalarının ya da bir tanıdığının bulunmasıdır. Bu durum sığınmacıların sadece il olarak değil aynı zamanda Şanlıurfa'nın ilçeleri bağlamında da sosyal ağları yerleşim yerlerine karar vermelerinde etkili olmaktadır. $\mathrm{Bu}$ durumun çeşitli açılardan avantajları olabileceği gibi sığınmacıların sosyal ağlarına yakın yerlerde ikamet etmeyi tercih etmeleri yerel halkla olan etkileşimi de azaltmaktadır (Karademir \& Doğan, 2019, s. 122). Buradan yola çıkarak sosyal ağların gettolaşmada önemli bir belirleyici rolünün olduğu ifade edilebilir Bu durum da beraberinde çeşitli uyum ve dâhil edilme sorunlarını getirebilmektedir.

\section{Göçün Sürekliliği}

Sosyal ağ kuramı, sonradan göç eden göçmenlerin ilk gelen göçmenlerin tecrübelerinden faydalandığını ve bu şekilde göçün kendini sürekli devam ettiren bir durum ortaya çıkardığını ileri sürmektedir (Wilpert, 1992; Yalçın, 2004, s. 50). Örneğin mülakatlarda katılımcılar buna ilişkin şu ifadelere yer vermişlerdir:

Yirmiden fazla aile bize geldi ve yardım istedi. Dayılarım amcalarım kuzenlerim babamın arkadaşları benim arkadaşlarım ve uzaktan akrabalarımız bizde uzun sürelerde kalıyorlardı. Kendilerine iş ve ev bulana kadar onları yardım ediyorduk. Bir aileden hariç o aileyi hiç tanımıyorduk bir gün babam dışardan geldi ve onunla birlikte bir anne ve iki çocuktan oluşan bir aile vardı. Babam onları sokakta kalırken çok kötü bir durumda olduklarını görmüş ve bizim eve getirmiş. Bizde yaklaşık on gün oturdular sonra Suriye'ye döndüler ve yakınımız olsa da olmasa da kimin yardım ihtiyacı olursa her zaman yardım edeceğiz (G5, 25, Erkek).

Dayım Suriye'den geldi bizden sonra. O da bizden daha çok zor bir yolla geldi kendisi iki çocuk sahibi ve eşi o zamanda hamileydi, bir süre bizde oturdu ve yerleşmek için yardım ettik ve ona bir iş bulduk ama maalesef çok az bir maaş alıyordu. Bu maaşla onun için 
Şanlıurfa'da kalmak çok zordu eşi çalışamaz çocukları daha çok küçük Avrupa'da daha iyi bir hayat kazanacağ düşündü ve Avrupa'ya göç etti (G11, Kadın, 22)

Görüldüğü üzere sığınmacılar kendi yakın akrabaları olmasa bile yeni gelecek sığınmacılara yardım etme isteği taşımaktadırlar. Bu durum aynı durumu paylaşma haliyle açıklanabilir. Diğer bir ifadeyle zorunlu göç sürecini yaşamaya devam eden göçmenler bu sürece yeni başlamış ve yardıma ihtiyacı olan göçmenlere destek olma isteği taşımaktadırlar. Bu durum da bir şekilde göçün devamlılığını sağlamakta ve daha fazla insanın Türkiye'ye sığınmasını teşvik etmektedir. Her ne kadar göç süreci zorunlu olsa da Türkiye'deki sosyoekonomik imkânların bilinirliliği sosyal ağlar vasıtasıyla yaygınlaştırılmakta ve yeni göçmenlerin göç etme karar sürecini hızlandırıcı ve kolaylaştırıcı rol oynamaktadır. Bununla birlikte Türkiye'de sosyal ağları güçlenen sığınmacılar artık kendilerini Türkiye' de kalıcı hissetmektedir. Böylelikle güçlenen sosyal ağlarla sığınmacılar kaybedilen bir vatanın ardından yeni bir vatan bulma ve yuvadan uzakta bir yuva sürecini başlatmış olmaktadırlar.

\section{Gelecek Beklentileri}

Yapılan görüşmeler sonucunda elde edilen bulgulardan birisi de Suriyeli sığınmacıların büyük bir bölümünün artık ülkelerine geri dönmek istemeyişleridir. Sığınmacılar bu durumu Türkiye'de bir hayat kurduklarına ve Suriye'deki iç karışıklıklarından devam etmesine bağlamaktalardır. Uzun yıllardır Türkiye'de yaşayan Suriyeli sığınmacıların kalıcılık eğilimleri son derece güçlenmiş durumdadır (Erdoğan, 2020). Türkiye'deki Suriyeliler konulu bir araştırma kapsamında Türkiye'nin gerçeklerle yüzleşmesi, stratejik kararını alması, Suriyelileri "misafir" değil, artık Türkiye'de yaşayacak insanlar olarak kabul etmesi gerekliliği üzerine durulmuştur (Erdoğan, 2019). Pek çok sığınmacı tarafından, kolay ulaşılabilir ve güvenli ülke olarak kabul edilen Türkiye, bir transit ülke olmaktan çıkmakta ve hedef ülke haline gelmektedir. Bu durum da Türkiye'nin sorumluluğunu daha da arttırmaktadır. Artan bu sorumluluk zaman zaman toplumsal tepkilere yol açarken, birtakım siyasal, ekonomik ve toplumsal sıkıntıları da beraberinde getirdiği görülmektedir (Aslantürk, 2020). Dolayısıyla sığınmacıların gelecek planları ve düşünceleri önemli bir soru olarak ortaya çıkmaktadır. 
Sığınmacı ve Türk vatandaşlığı almış Suriyeli üniversite öğrencilerinin gelecek beklentileri hakkında yapılan çalışmalarda öğrencilerin Avrupa'ya doğru hareket etme niyetinde olduğu ortaya çıkmıştır (Gülerce \& Çorlu, 2021; Gülerce, 2021). Türkiye içinde yaşanılan şehirden başka bir şehre göç ile Avrupa'ya ya da başka bir Arap ülkesine göç etmeyi düşünme konusunda en düşük ortalama değerlerin ortaya çıkması önemli verilerdir. Suriyelilerin Avrupa'ya göç etme konusunda bazı dini hassasiyetlerini ve kültürel farklılıklarını dile getirdikleri anket hazırlanırken yapılan pilot uygulamada ve anket sırasında dile getirilmiştir. Ancak kendilerine etnik köken ve dil konusunda çok daha yakın olan Arap ülkelerini tercih etmeyi düşünmemeleri de ilginç bir sonuçtur (Akin \& Bozbaş, 2020). Diğer bir çalışmada katılımcıların Suriye'deki iç savaşın bitmesinden sonra ülkelerine geri dönme veya farklı bir ülkeye gitme fikrine sıcak bakmadıkları görülmüştür. 20 katılımcıyla yapılan görüşmede 18'i ülkelerine geri dönmeyi düşünmediklerini ancak 50 yaş üstü olan 2 katılımcı ise güvenliğin sağlanması durumunda geri dönmek istediklerini ifade etmiştir (Karademir \& Doğan, 2019, s. 123). Diğer bir çalışmada ise şuanda Suriye'nin içerisinde bulunduğu durum ve şartlar göz önünde bulundurulduğunda eğer bir geri dönüş gerçekleşebilecekse bile bu durumun önemli oranda etnik temelli olacağı ortaya çıkmıştır (Sönmez \& Şahin, 2021). Dolayısıyla geri dönüş kararını etkileyecek birçok faktör ortaya çıkmaktadır.

Çalışmamız kapsamında yapılan mülakatlarda bir katılımcı "ülkelerine geri dönüp dönmeme ve gelecek planları” üzerine sorulan bir soruya şöyle yanıt vermiştir:

Birçok nedenden dolayı ülkeme geri dönmek istemiyorum:

- Türk topluluğuyla yaşadım ve şehir merkezinde mahalle sakinleri ile samimi ve kardeşlik içinde yaşıyorum. Komşular beni çok seviyor ve onları çok seviyorum, sekiz yıldır aynı evde kiracı olarak yaşıyorum. Bu süre içerisinde kimseyle sorun yaşamadım.

- Çocuklarım Türk okullarında ve üniversitelerinde okuyor ve bu ülkede Türk halkının ve geleceklerinin bir parçası haline geldi.

- Suriye'de ne güvenlik, ne adalet ve ne de emniyet var. Bunlarla birlikte Suriye'de ne malım ne de mülküm kaldı. 
- İleride bazı şeyler yoluna girerse sadece akrabalarımı ziyaret etmek için Suriye'ye gidebilirim (G1, Erkek, 53).

Suriye'den Türkiye'ye 10 yıl önce göç etmiş olan bir sığınmacı, Türkiye'de hayatını devam ettirmesi için Türkiye'de yaşadığı süre, yerel halkla ilişkilerinin iyi olması, eğitim, güvenlik, adalet ve Suriye'de devam eden iç karışıklıklar gibi birçok neden ortaya koymaktadır. Burada dikkat çeken noktanın özellikle Türkiye' de kalış süreci, bağların artması ve kopamaz hale gelmesidir şeklinde ifade edilebilir.

\section{Sonuç ve Tartışma}

Sosyal ağlar, göç ve göç süreçlerini anlamada ve açıklamada kullanılan önemli bir kavramdır. Yeni göçmenler kendilerinden önce göç eden eski göçmenlerin tecrübelerinden faydalanarak göç süreçlerini kolaylaştırmaktadırlar. Sosyal ağlar, sadece isteğe bağlı göçlerde değil zorunlu göç hallerinde de özellikle göçmenlerin göç nedenlerini, karar alma, yolculuk, göç edilecek yerin seçimi gibi süreçleri belirlemektedir. Bunun yanında göç edilen ülkede göçün sürekliliğini koruma ve göçmenlerin gelecek beklentileri de önemli ölçüde sosyal ağlara bağlıdır. Bu çalışmada sosyal ağlar kuramı yardımıyla Şanlıurfa'da yaşayan Suriyeli sığınmacıların göç süreçleri değerlendirilmiştir.

Katılımcılarla yapılan yarı yapılandırılmış mülakatlar sonucunda elde edilen bulgular Suriyeli sığınmacıların göç etme kararı vermeleri aşamasında sosyal ağların etkili olduğunu göstermiştir. Özellikle akrabalık ve arkadaşlık bağlarının göç etme kararı verme aşamasında belirleyici olduğu hatta bu süreci önemli derecede kolaylaştırdığ görülmüştür. Özellikle göçmenlerin Şanlıurfa'da bulunan yakın akrabalarının karar verme aşamasında çok etkili olduğu yapılan görüşmelerde ortaya çıkmıştır.

Sığınmacıların göç yolculuklarında çeşitli zorluklarla karşılaştıkları ancak bu zorlukları önemli ölçüde sosyal ağlar vasıtasıyla kolaylaştırdıkları çalışmanın sonuçları arasında yer almaktadır. Özellikle sığınmacıların büyük çoğunluğunun yasadışı yollarla Türkiye sınırından geçen düzensiz göçmen olmaları göz önünde bulundurulduğunda göç yolculuğunda oluşabilecek risk ve maliyet faktörlerini sosyal ağlar aracılığıyla en aza indirmeye çalıştıkları anlaşılmıştır. Dolayısıyla bu durum her ne kadar zorunlu göç de olsa yeni gelecek olan göçmenler için teşvik edici olmakta ve göçün sürekliliğini de beraberinde 
getirmektedir. Bunun yanında daha önce göç eden sığınmacıların daha sonra gelecek olan sığınmacılara göç süreçlerinde yardım etmeleri bu düşünceyi desteklemektedir.

Göçmenler arasında oluşturulan sosyal ağların insanların hangi şehre göç edeceklerine verdikleri kararda önemli rol oynamaktadır. Sığınmacılar Türkiye'ye gelmeden önce Şanlıurfa'da yaşamaya karar vermişlerdir. Bu kararın temel nedenlerinden birisi sığınmacıların Şanlıurfa'da bulunan akrabalarının veya tanıdıklarının bulunmasıdır. Böylelikle göç ettikleri şehirde dayanışma içerisinde yaşayarak zorunlu göçün beraberinde getirdiği sıkıntılara karşı dayanıklılıklarını güçlendirmektedirler. Bunun yanında sosyal ağların göçmenlerin Şanlıurfa' da yaşamlarını ve yerleşikliklerini ve Türkiye'de kalıcı oldukları yönündeki niyetlerini güçlendirdiği ortaya çıkmıştır.

Şanlıurfa'da yaşayan sı̆̆ınmacılar göç tecrübelerini kullanarak yeni göç edecek göçmenlere de yol göstermekte ve onlarla dayanışma içerisinde olmaktadırlar. Dolayısıyla iletişim ve ulaşım teknolojilerinin de gelişmesiyle birlikte bu durum, yeni göçmenlerin Türkiye’ye düzenli veya düzensiz bir şekilde göç etmeye zamanla artarak devam edeceklerini göstermektedir. Sonuç olarak sosyal ağlar göç süreçlerinin tamamında etkili olmakla birlikte özellikle karar alma aşamasında ve yer seçiminde önemli bir yere sahiptir. Özellikle göçmenler arasındaki akrabalık bağları çok belirleyicidir. Bunun dışında sosyal ağlar zincirleme göçü tetiklemekte olup gelecekte Suriye'den Türkiye'ye göçte etkili olmaya devam edeceği ifade edilebilir.

\footnotetext{
Hakem Değerlendirmesi: Dış bağımsız.

Çıkar Çatışması: Yazarlar çıkar çatışması bildirmemiştir.

Finansal Destek: Yazarlar bu çalışma için finansal destek almadığını beyan etmiştir.

Peer-review: Externally peer-reviewed.

Conflict of Interest: The authors have no conflict of interest to declare.

Grant Support: The authors declared that this study has received no financial support.
} 


\section{Kaynakça/References}

Abadan-Unat, N. (2017). Bitmeyen Göç: Konuk Iş̧̧ilikten Ulus-Ötesi Yurttaşlı̆̆a. İstanbul: İstanbul Bilgi Üniversitesi. Geliş tarihi gönderen https://bilgiyay.com/kitap/ bitmeyen-goc-konuk-iscilikten-ulus-otesi-yurttasliga/

Adıgüzel, Y. (2017). Göç Sosyolojisi. Ankara: Nobel Yayınları.

Akin, M. H., \& Bozbaş, G. (2020). Suriye'den Türkiye'ye Göçün Sosyolojik Sonuçları: Suriyeli Göçmenler Üzerine Uygulamalı Bir Saha Araştırması. Liberal Düşünce Dergisi, 25(97), 47-65. https://doi.org/10.36484/liberal.692459

Aslantürk, O. (2020). Türkiye’ye yönelik göç ve iltica hareketleri: suriyeliler örneği migration and asylum movements towards turkey: Syrian case. Mehmet Akif Ersoy Üniversitesi Iktisadi ve Idari Bilimler Fakültesi Dergisi, 7(1), 172-201. https://doi. org/10.30798/makuiibf.581436

Bal, H. (2014). Sosyolojide Yöntem ve Araştırma Teknikleri. Bursa: Sentez Yayıncılık.

Bartram, D., Poros, M. V., \& Monforte, P. (2017). Göç Meselesinde Temel Kavramlar (I. Ağabeyoğlu Tuncay, Çev.). Ankara: Hece. Geliş tarihi gönderen https://www. kitapyurdu.com/kitap/goc-meselesinde-temel-kavramlar-/419641.html

Bimay, M. (2020). Onuncu Yılında Suriyeli Sığınmacıların Kente Entegrasyonu ve Gelecek Beklentileri: Batman Örneği. Mukaddime, 11(2), 348-381. https://doi. org/10.19059/mukaddime.790661

Bozkurt, V., Kaya İnceiplik, G., \& Baigabylov, N. (2021). Göçmenlere Yönelik Tutumları Etkileyen Değerler ve Demografik Faktörler. Iç̧inde Göç ve Etkileri Güvenlik, Toplum, Kadın, Çocuk, Ekonomi, Dış Politika (1. bs, ss. 53-69). Ankara: Pegem Akademi.

Boyd, M. (1989). Family and Personal Networks in International Migration: Recent Developments and New Agendas. The International Migration Review, 23(3), 638670. https://doi.org/10.2307/2546433

Bulut, Y., \& Akın, S. (2020). Göçe İlişkin Kavram ve Kuramlar. İçinde Y. Bulut \& S. Akın (Ed.), Yerel, Ulusal ve Küresel Boyutlarlyla Göç ve Mülteci Sorunu (ss. 71-110). Konya: Çizgi.

Castles, S., \& Miller, M. J. (2008). Göçler çă̆ı: Modern dünyada uluslararası göç hareketleri (B. U. Bal \& İ. Akbulut, Çev.). İstanbul: İstanbul Bilgi Üniversitesi.

Çağlayan, S. (2006). Göç kuramları, göç ve göçmen ilişkisi. Muğla Üniversitesi Sosyal Bilimler Enstitüsü Dergisi, (17), 67-91.

Directorate General of Migration Management. (2021). Geliş tarihi 30 Ocak 2021, gönderen TEMPORARY PROTECTION website: https:/en.goc.gov.tr/temporaryprotection 27

Emini, F. T. (2018). Göç Sonrası Sorunların Çözümünde Sivil Toplum Stratejisi. Bursa: Ekin

Erdoğan, M. M. (2019). Türkiye'deki Suriyeli Mülteciler. Ankara: Konrad Adenauer Stiftung. 
Erdoğan, M. M. (2020). Suriyeliler Barometresi 2019, Suriyelilerle Uyum Iç̧inde Yaşamın Çerçevesi. Ankara: Orion Kitabevi.

Faist, T. (2003). Uluslararası Göç ve Ulusaşııı Toplumsal Alanlar, (Çev. A. Z. Gündoğan, C. Nacar), Bağlam Yayınları, İstanbul.

Göç İdaresi Başkanlığı. (2021, Ocak 20). Geliş tarihi 20 Ocak 2021, gönderen Geçici Koruma website: https://www.goc.gov.tr/gecici-koruma5638

Gözübüyük, M., Kemik, P., \& Sever, M. (2019). Suriyeli Sığınmacıların Yoğun Yaşadığg Bölgelerdeki Yerel Halkın Suriyeli Sığınmacılara İlişkin Görüşleri: Altındağ Örneği. Mukaddime, 10(2), 582-596. https://doi.org/10.19059/mukaddime.553210

Gurak, DT and Caces, FE. 1992. Migration Networks and the Shaping of Migration Systems. In: Kritz, M, Lim, LL and Zlotnix, H (eds.), International Migration Systems. Oxford: Clarendon Press. pp. 150-186.

Gülerce, H. (2020). Göç ve Belirsizlik: Eşleri Kayıp Suriyeli Sığınmacı Kadınlar. insan \& toplum, 10(3), 217-221. https://dx.doi.org/10.12658/V0001

Gülerce, H., \& Çorlu, R. (2021). Yükseköğretimdeki Suriyeli Sığınmacı Öğrenciler: Uyum ve Çatışma Alanları. Üsküdar Üniversitesi Sosyal Bilimler Dergisi, (12), 71106. https://doi.org/10.32739/uskudarsbd.7.12.85

Gülerce, H. (2021). Türk Vatandaşlığı Almış Suriyeli Üniversite Öğrencileri ve Sosyal Uyum. İçinde Karadeniz, S., ve Çiçek, N. (Ed.) Mültecilik ve Vatandaşlık: Göç Çă̆ında Aidiyet, Haklar ve Gelecek Sorunu. Mardin Artuklu Üniversitesi Yayınları, Mardin.

Güllüpınar, F. (2013). Göç Olgusunun Ekonomi-Politiği ve Uluslararası Göç Kuramları Üzerine Bir Değerlendirme. Yalova Sosyal Bilimler Dergisi, 2(4).

Karademir, D., \& Doğan, M. (2019). Suriyeli Mültecilerin Mekânsal Analizi: Şanlıurfa Örneği. Coğrafya Dergisi, (39), 111-124. https://doi.org/10.26650/JGEOG2019-0053

Karasu, M. A. (2018). Suç Korkusu, Göç ve Suriyeli Sı̆̆ınmacılar: Şanlıurfa Örneği. Uluslararası Yönetim Akademisi Dergisi, 1(3), 332-347.

Karasu, M. A. (2020). Göç ve Güvenlik Üzerine Kavramsal Bir Çerçeve. İçinde Y. Bulut \& S. Akın (Ed.), Yerel, Ulusal ve Küresel Boyutlarıyla Göç ve Mülteci Sorunu (ss. 71110). Konya: Çizgi.

Kaya, M. (2017). Türkiye'deki Suriyeliler: İç içe geçişler ve karşılaşmalar. İstanbul: Hiperlink.

Massey, D. S., Arango, J., Hugo, G., Kouaouci, A., Pellegrino, A., \& Taylor, J. E. (2014). Uluslararası göç kuramlarının bir değerlendirmesi. Göç Dergisi, 1(1), 11-46. https:// doi.org/10.33182/gd.v1i1.546

McLuhan, M. (1992). The Global Village: Transformations in World Life and Media in the 21st Century. New York.

Ok, G., \& Gülerce, H. (2021). Türkiye'de Göç ve Uyum Çalışmaları: Sosyal Girişimcilik Yoluyla Sosyal Dahil Etme Projesi Örneği. Içinde Göç ve Etkileri Güvenlik, Toplum, Kadın, Çocuk, Ekonomi, Dış Politika (1. bs, ss. 22-33). Ankara: Pegem Akademi. 
Ökten, Ş. (2017). Forced Migration, Unwanted Acceptance, Uncertain Future of Syrian Refugees: The Struggle for Legal Status. European Journal of Interdisciplinary Studies Articles, 9(1), 156-164. https://doi.org/10.26417/ejis.v3i4.p156-164

Özcan, E. D. E. (2017). Çağdaş Göç Teorileri Üzerine Bir Değerlendirme. İş ve Hayat, 2(4), 183-215.

Portes, A., \& Sensenbrenner, J. (1993). Embeddedness and Immigration: Notes on the Social Determinants of Economic Action. American Journal of Sociology, 98(6), 1320-1350. http://www.jstor.org/stable/2781823

Sakız, H. (2015). Bütünleştirici bir Göç Psikolojisinin Oluşturulması. Göç Araştırmaları Dergisi, (1), 150-175.

Sakız, H. (2019). Kapsayıcılık Paradigması Çerçevesinde Göçmen Bireyler. Içinde Türkiye'de Göçmen Kapsayıcılı̆̆ı Sorundan Fırsata Dönüşüm Önerileri (ss. 1-13). Ankara: Pegem Akademi.

Sönmez, M. E., \& Ayik, U. (2020). Sınır İllerindeki (Gaziantep, Hatay ve Şanlıurfa) Suriyeli Sı̆̆ınmacıların Sosyal, Ekonomik ve Nüfus Yapıları. Gaziantep Üniversitesi Ayıntab Araştırmaları Dergisi, 3(2), 64-75.

Sönmez, M. E. \& Şahin, Ş. (2021). Gaziantep’teki Suriyeli Sığınmacıların Etnik Kökenlerine Göre Geri Dönüş Eğilimleri . Gaziantep Üniversitesi Ayıntab Araştırmaları Dergisi , 4 (1) , 37-51 . Retrieved from https://dergipark.org.tr/tr/pub/ gunaad/issue/63577/957127

Suriye Acil Durumu. (2021). Geliş tarihi 05 Şubat 2021, gönderen UNHCR Türkiye website: https://www.unhcr.org/tr/suriye-acil-durumu

Wilpert, C. (1992). The use of social networks in Turkish migration to Germany. İçinde M. M. Kritz, L. L. Lim, \& H. Zlotnik (Ed.), International Migration Systems: A Global Approach (ss. 177-189). Oxford: Clarendon Press.

Yalçın, C. (2004). Göç Sosyolojisi. Ankara: Anı Yayıncılık. Geliş tarihi gönderen https:// www.kitapyurdu.com/kitap/goc-sosyolojisi/69613.html

Yıldırım, A., \& Şimşek, H. (2017). Sosyal Bilimlerde Nitel Araştırma Yöntemleri. Ankara: Seçkin Yayıncılık.

Yıldız, A. (2017). Göç ve Entegrasyon Politikalarında Vatandaşlık. Göç Araştırmaları Dergisi, 3(1), 36-67. 
